\title{
MunKaÉRTÉK PREFERENCIÁK \\ a Babeş-Bolyai Tudományegyetem \\ HALLGATÓI KÖRÉBEN
}

\author{
Müller-Fábián Andrea
}

\begin{abstract}
Our research investigated the work- and carrier-related preferences of students attending different specializations (e.g., sociology, social work, psychology, law, theology, etc.) at the Babes-Bolyai University from Cluj-Napoca, Romania. Our sample included students from both the Hungarian and Romanian study lines of this multicultural university. In our investigation we relied on the following research instruments: the Super work-value questionnaire under its adapted form (Csepeli and Somlai, 1978) and a questionnaire relating to students' work-recrutation and carrier-related motivations which was previously applied in practice by the University of Debrecen. In our investigation took part 161 students, $55 \%$ of them being Hungarian and $45 \%$ of them having Romanian nationality. The majority of the students were female.

The results show that in the case of work-related preferences, Hungarian students attach higher importance to diversity, autonomy and altruism, while students with Romanian nationality appreciate more than their Hungarian counterparts the material benefits of work and the role of guidance at the workplace. On the level of the pooled sample the common factors are represented by power, freedom, self-expression and safety. We appreciate that the appearance of the freedom factor should be judged as a positive sign, since it involves, besides diversity and autonomy, the importance of creativity as well.
\end{abstract}

Keywords: work-related preferences, carrier options, students' recrutation, value orientation, value preferences

DOI: $10.19055 / \mathrm{ams} .2013 .4 / 10 / 3$

\section{Bevezetés}

Jelen tanulmány a Debreceni Egyetem Egészségügyi Karával közösen végzett, TÁMOP 4.2.2-B pályázat által támogatott "Hallgatói munkaérték preferenciák és iskolai egészség- 
magatartás nemzetközi összehasonlító vizsgálata magyarországi, romániai és ukrajnai mintán" elnevezésü kutatási projekt keretében, kolozsvári egyetemi hallgatók körében végzett munkaérték preferenciákkal kapcsolatos vizsgálat eredményeit összegzi.

A vizsgálat a Kolozsvári Babeş-Bolyai Tudományegyetem négy karának hallgatói munkaérték preferenciájára, pályaválasztására valamint a hallgatók rekrutációjára terjedt ki. Célja a szociológiai és szociális munka, bölcsészettudományi, müvészeti, neveléstudományi, pszichológiai, társadalomtudományi, jogi politikai, közigazgatási, európai és teológiai, egyházi, vallási karok hallgatóinak sajátos, munkával kapcsolatos értékorientációjának bemutatása, a magyar és román anyanyelvủ hallgatók értéksorrendjében jelentkező sajátosságok feltárása.

\section{A Babeș-Bolyai Tudományegyetem föbB}

Annak érdekében, hogy átfogóbb képet alkothassunk arról, hogy milyen városban, milyen egyetemen élnek/járnak a vizsgálatban szereplő hallgatók, fontosnak tartjuk pár mondat erejéig bemutatni Kolozsvárt és a Babeş-Bolyai Tudományegyetemet.

Kolozsvár Erdély legrégibb és Románia egyik legnépesebb városa, Kolozs megye székhelye, megyei rangú város. Lakosainak száma a 2011-es népszámlálás adatai szerint 309136 fö. Ebből román 247548 (80,07\%), magyar 49375 (15,97\%), német 520 $(0,16 \%)$, roma $3274(1,05 \%)$, zsidó $159(0,05 \%)$, egyéb nemzetiségü $2049(0,66 \%)$ és nem nyilatkozott 6211 (2\%) (Comisia județeană pentru recensământul populaţiei şi al locuinţelor, judeţul cluj, 2012).

Az erdélyi magyar mủvelődési, s ezen belül az irodalmi és mủvészeti, valamint tudományos élet központja. Magyar színháza, operája, magyar nyelven is müködő egyeteme, föiskolái, könyvkiadói, rádió- és tévéstúdiói vannak, a városban több folyóirat és újság jelenik meg magyarul (Asztalos, 2013).

Történelme folyamán Kolozsvár mindig fontos iskolaváros volt, iskolái századokon át szellemi kincsekkel árasztották el egész Erdélyt (ibidem, 2013).

1581-ben Báthory István erdélyi fejedelem alapította Kolozsvár első felsőfokú iskoláját, a jezsuita kollégiumot.

A mai értelemben vett tudományegyetem 1872 októberétől müködik Kolozsváron (Eötvös József és Pauler Tivadar kultuszminiszterek törvényjavaslata alapján négy karral indított: bölcsész, matematikai-természettudományi, jogi és orvosi (Sipos, 2013).

A Romániában érvényben lévő egyetemi besorolások alapján a Babeş-Bolyai Tudományegyetem kutatóegyetem. Az egyetemen 21 viszonylag önálló kar müködik, a három erdélyi történelmi nyelv alapján tanulmányi tagozatokra oszlik (román, magyar és német). Körülbelül 45000-re tehető a hallgatók létszáma, és több mint 1500 egyetemi oktatója van. Összesen 262 akkreditált alapképzési program müködik az egyetemen, amiből 72 alapképzési program magyar tagozaton (www.ubbcluj.ro). 


\section{A minta bemutatása}

A vizsgálatban szereplő hallgatók egy nagyvárosban, Erdély kulturális fővárosában, és egyben legelismertebb egyetemén tanulnak.

A kiválasztási eljárás módja az volt, hogy az adott szak minden II. éves nappali tagozatos hallgatója meghívást kapott a vizsgálatban való részvételre. A méréseket azokkal a hallgatókkal végeztük el, akik eleget tettek ennek a meghívásnak. A viszgálatban összesen 161 egyetemi hallgató vett részt, amiből 88 magyar nemzetiségü $(54,7 \%)$ és 73 román nemzetiségü $(45,3 \%)$ volt. (1. táblázat) A magyar nemzetiségüek közül 18,39\%-uk férfi és $81,61 \%$-uk nő. Hasonló az arány a román nemzetiségủek esetében is, hiszen közülük $87,1 \%$ nö és $12,9 \%$ férfi. Életkorukat tekintve $19-49$ év közöttiek.

1. táblázat: A vizsgált populáció nemzetiség szerinti megoszlása

\begin{tabular}{|l|c|c|}
\hline Nemzetiség & Fő & Százalék (\%) \\
\hline magyar & 88 & 54.7 \\
\hline roman & 73 & 45.3 \\
\hline összesen & 161 & 100.0 \\
\hline
\end{tabular}

Forrás: BBTE-DE EK TÁMOP kutatás adatfelvétele

A vizsgálat eszközei a következők voltak: A SUPER-féle fejlődéselmélet és a munkaérték kérdőív Csepeli- Somlai-féle adaptált változata (Csepeli és Somlai, 1978) és egy a pályarekrutációval és pályamotivációval kapcsolatos kérdőív (a kérdőivet a Debreceni Egyetem Tehetséggondozó Programja beválogatási eljárásához alkalmazták, ez került adaptálásra).

A vizsgálatban résztvevő 161 személyből 93 (57,8\%) a szociológia és szociális munkás képző kar hallgatója, 27 (16,8\%) a bölcsésztudományi, művészeti kar hallgatója, $17(10,6 \%)$ társadalomtudományi, jogi kar hallgatója, $20(12,4 \%)$ a teológia, egyházi, vallási kar hallgatója, míg 4 hallgató $(2,5 \%)$ nem tüntette fel, hogy milyen kar hallgatója. (2. táblázat)

A vizsgálati mintát alkotó szociológia és szociális munkás képző kar 93 hallgatója közül 57 román szakon és 36 magyar szakon járt. A 27 bölcsésztudományi, müvészeti kar hallgatója közül 26 magyar szakos és 1 román szakos hallgató volt. A vizsgálatban résztvevő 17 társadalomtudományi, jogi kar hallgatói közül 15 magyar szakos és 2 román, míg a 20 teológia, egyházi, vallási kar hallgatói közül 9 magyar szakon és 11 ro mán szakon tanuló hallgató volt.

A vizsgálatban résztvevő hallgatók 19,3\%-a Kolozsváron, 1,9\% Fővárosban, 19,3\% Megyeszékhelyen, 32,9\%-uk más városban, 19,3\% falun és 3,7\%-uk külföldön (Magyarországon) járt iskolába (3. táblázat) . 
2. táblázat: A vizsgált populáció kar/intézet szerinti megoszlása

\begin{tabular}{|l|c|c|}
\hline Kar/intézet & $\begin{array}{c}\text { Fő } \\
\text { (az egész } \\
\text { tanulmányban) }\end{array}$ & Százalék (\%) \\
\hline Szociológiai és szociális munka & 93 & 57.8 \\
\hline Bölcsészettudományi, müvészeti & 27 & 16.8 \\
\hline Társadalomtudományi, jogi & 17 & 10.6 \\
\hline Teológiai, egyházi, vallási & 20 & 12.4 \\
\hline hiányzó adat & 4 & 2.5 \\
\hline összesen & 161 & 100.0 \\
\hline
\end{tabular}

Forrás: BBTE-DE EK TÁMOP kutatás adatfelvétele

3. Táblázat: A vizsgált populáció általános iskola helye szerinti megoszlása

\begin{tabular}{|l|c|c|}
\hline Iskola helye & Fő & Százalék (\%) \\
\hline Főváros & 3 & 1.9 \\
\hline Kolozsvár & 31 & 19.3 \\
\hline Megyeszékhely & 31 & 19.3 \\
\hline Egyéb város & 53 & 32.9 \\
\hline Falu & 31 & 19.3 \\
\hline Külföld (Magyarország) & 6 & 3.7 \\
\hline Egyéb & 5 & 3.1 \\
\hline Hiányzó adatl & 1 & .6 \\
\hline összesen & 161 & 100.0 \\
\hline
\end{tabular}

Forrás: BBTE-DE EK TÁMOP kutatás adatfelvétele

A vizsgálati minta 1,8\%-a fővárosi iskolába járt, amiből 0,6\% magyar nemzetiségü, és 1,2\% román nemzetiségủ egyetemi hallgató. A 19,3\% Kolozsváron járó hallgató közül $6,8 \%$ magyar és $12,5 \%$ román; a 19,3\% megyeszékhelyen járó hallgató $12,5 \%$-a magyar és 6,8\%- a román; a 33,1\% más városban járó hallgató közül 15,6\% magyar és $17,5 \%$ román anyanyelvü. (4. táblázat) 
4. Táblázat: Hol járt általános iskolába nemzetiség szerint (szám, \% megoszlás)

\begin{tabular}{|l|c|l|c|c|c|c|}
\hline $\begin{array}{c}\text { Hol járt általános } \\
\text { iskolába }\end{array}$ & \multicolumn{6}{|c|}{ Nemzetiség } \\
\hline & magyar & $\%$ & román & $\%$ & \multicolumn{2}{|c|}{ összesen } \\
\hline Főváros & 1 & 0.62 & 2 & 1.25 & 3 & 1.87 \\
\hline Kolozsvár & 11 & 6.87 & 20 & 12.5 & 31 & 19.37 \\
\hline Megyeszékhely & 20 & 12.5 & 11 & 6.87 & 31 & 19.37 \\
\hline Egyéb város & 25 & 15.62 & 28 & 17.5 & 53 & 33.12 \\
\hline Falu & 21 & 13.12 & 10 & 6.25 & 31 & 19.37 \\
\hline $\begin{array}{l}\text { Külföld } \\
\text { (Magyarország) }\end{array}$ & 6 & 3.75 & 0 & 0 & 6 & 3.75 \\
\hline Egyéb & 3 & 1.87 & 2 & 1.25 & 5 & 3.125 \\
\hline összesen & 87 & 54.37 & 73 & 45.62 & 160 & 100 \\
\hline
\end{tabular}

Forrás: BBTE-DE EK TÁMOP kutatás adatfelvétele

A vizsgálat során kiderült, hogy a résztvevők $80,7 \%$-a önkormányzati, állami fenntartású általános iskolába járt, míg 10\%-uk az egyház által támogatott általános iskolába járt. (5. táblázat)

5. Táblázat: Milyen fenntartású volt az általános iskola

\begin{tabular}{|l|c|c|}
\hline $\begin{array}{c}\text { Milyen fenntartású volt } \\
\text { az általános iskola }\end{array}$ & Fö & Százalék (\%) \\
\hline önkormányzati, állami & 130 & 80.7 \\
\hline egyházi & 10 & 6.2 \\
\hline alapítványi, magán & 1 & 0.6 \\
\hline magyar & 14 & 8.7 \\
\hline egyéb & 4 & 2.5 \\
\hline hiányzó adat & 2 & 1.2 \\
\hline összesen & 161 & 100.0 \\
\hline
\end{tabular}

Forrás: BBTE-DE EK TÁMOP kutatás adatfelvétele 
Amint az alábbi táblázatban (6. táblázat) látható, hasonló az eloszlás az önkormányzat által fenntartott általános iskolába járó magyar és román hallgatók között $(39,6 \%$-a a magyar hallgatóknak és 42,1\%-a a román hallgatóknak tanult ilyen típusú iskolában).

6. Táblázat: Milyen fenntartású volt az általános iskola nemzetiség szerint (szám, \%-os megoszlás)

\begin{tabular}{|l|c|c|c|c|c|c|}
\hline $\begin{array}{c}\text { Milyen fenntartású volt } \\
\text { az általános iskola }\end{array}$ & \multicolumn{7}{|c|}{ Nemzetiség } \\
\hline & magyar & $\%$ & román & $\%$ & \multicolumn{2}{|c|}{ összesen } \\
\hline önkormányzati, állami & 63 & 39,6 & 67 & 42,13 & 130 & 81,76 \\
\hline egyházi & 9 & 5,66 & 1 & 0,61 & 10 & 6,28 \\
\hline alapítványi, magán & 0 & 0 & 1 & 0,61 & 1 & 0,62 \\
\hline magyar & 14 & 8,8 & 0 & 0 & 14 & 8,80 \\
\hline egyéb & 1 & 0,61 & 3 & 1,88 & 4 & 2,51 \\
\hline összesen & 87 & 54,71 & 72 & 45,29 & 159 & 100 \\
\hline
\end{tabular}

Forrás: BBTE-DE EK TÁMOP kutatás adatfelvétele

A középiskola típusa szempontjából a legtöbb hallgató gimnáziumban végzett (80\%), és ez érvényes mind a magyar mind a román hallgatók esetében $(42,1 \%$ illetve $38,9 \%)$. (7. táblázat)

7. Táblázat: Milyen jellegü középiskolába járt nemzetiség szerint (szám, \%-os megoszlás)

\begin{tabular}{|l|c|c|c|c|c|c|}
\hline $\begin{array}{c}\text { Milyen jellegü } \\
\text { középiskolába járt }\end{array}$ & \multicolumn{6}{|c|}{ Nemzetiség } \\
\hline & $\begin{array}{l}\text { ma- } \\
\text { gyar }\end{array}$ & $\%$ & $\begin{array}{l}\text { ro- } \\
\text { mán }\end{array}$ & $\%$ & \multicolumn{2}{|l|}{ összesen } \\
\hline szakmunkásképző & 2 & 1,25 & 2 & 1,25 & 4 & 2,51 \\
\hline szakközépiskola & 13 & 8,17 & 3 & 1,88 & 16 & 10,06 \\
\hline gimnázium & 67 & 42,13 & 62 & 38,99 & 129 & 81,15 \\
\hline egyéb & 5 & 3,14 & 5 & 3,14 & 10 & 6,28 \\
\hline összesen & 87 & 54,71 & 72 & 45,29 & 159 & 100 \\
\hline
\end{tabular}

Forrás: BBTE-DE EK TÁMOP kutatás adatfelvétele 
A hallgatók 22,4\%-a Kolozsváron, míg 43,5\%-uk más városban érettségizett, de akadtak olyanok is, akik a falut jelölték be érettségi vizsgájuk helyszínéül (2,5\%). (8. táblázat)

8. Táblázat: Melyik településen érettségizett?

\begin{tabular}{|l|c|c|}
\hline Melyik településen érettségizett? & Fő & Százalék (\%) \\
\hline Főváros & 3 & 1.9 \\
\hline Kolozsvár & 36 & 22.4 \\
\hline Megyeszékhely & 31 & 19.3 \\
\hline Egyéb város & 70 & 43.5 \\
\hline Falu & 4 & 2.5 \\
\hline Külföld (Magyarország) & 5 & 3.1 \\
\hline Egyéb & 10 & 6.2 \\
\hline Hiányzó adat & 2 & 1.2 \\
\hline összesen & 161 & 100.0 \\
\hline
\end{tabular}

Forrás: BBTE-DE EK TÁMOP kutatás adatfelvétele

9. Táblázat: Melyik településen érettségizett nemzetiség szerint (szám, \%-os megoszlás)

\begin{tabular}{|l|c|c|c|c|c|c|}
\hline $\begin{array}{l}\text { Melyik településen } \\
\text { érettségizett }\end{array}$ & \multicolumn{6}{|c|}{ Nemzetiség } \\
\hline & magyar & $\%$ & román & $\%$ & összesen \\
\hline Főváros & 2 & 1,25 & 1 & 0,61 & 3 & 1,88 \\
\hline Kolozsvár & 16 & 10,06 & 20 & 12,57 & 36 & 22,64 \\
\hline Megyeszékhely & 20 & 12,57 & 11 & 6,91 & 31 & 19,49 \\
\hline Egyéb város & 43 & 27,04 & 27 & 16,98 & 70 & 44,02 \\
\hline Falu & 3 & 1,88 & 1 & 0,61 & 4 & 2,51 \\
\hline $\begin{array}{l}\text { Külföld } \\
\text { (Magyarország) }\end{array}$ & 4 & 2,51 & 1 & 0,61 & 5 & 3,14 \\
\hline Egyéb & 0 & 0 & 10 & 6,28 & 10 & 6,28 \\
\hline összesen & 88 & 55,3 & 71 & 44,65 & 159 & 100 \\
\hline
\end{tabular}

Forrás: BBTE-DE EK TÁMOP kutatás adatfelvétele 
Mind a magyar-, mind a román nemzetiségủ hallgatók többsége nem Kolozsváron, hanem más városban érettségizett $(27 \%, 16,9 \%)$. Érdekességképpen meg kell említenünk annak a román nemzetiségủ hallgatónak az esetét, aki azt jelölte be, hogy külföldön, Magyarországon érettségizett, azonban nem magyarul. (9. táblázat)

Az esetek többségében (78,9\%) önkormányzati, államilag támogatott iskolában érettségiztek a hallgatók. (10. táblázat)

10. Táblázat: Az érettségit adó iskola fenntartója

\begin{tabular}{|l|c|c|}
\hline \multicolumn{1}{|c|}{$\begin{array}{c}\text { Az érettségit adó } \\
\text { iskola fenntartója }\end{array}$} & Fő & Százalék (\%) \\
\hline önkormányzati, állami & 127 & 78.9 \\
\hline egyházi & 21 & 13.0 \\
\hline magyar & 9 & 5.6 \\
\hline egyéb & 3 & 1.9 \\
\hline hiányzó adat & 1 & .6 \\
\hline összesen & 161 & 100.0 \\
\hline
\end{tabular}

Forrás: BBTE-DE EK TÁMOP kutatás adatfelvétele

A továbbiakban láthatjuk, hogy a hallgatók 53,7\%-nak van nyelvvizsgája. Elgondolkoztató az a tény, hogy a román hallgatók több, mint kétszeresének $(37,3 \%)$ van nyelvvizsgája a magyar hallgatókhoz viszonyítva (16,4\%). (11. táblázat) Feltevődik a kérdés, hogy vajon ez a helyzet azért áll fenn, mert a magyar anyanyelvü hallgatóknak eleve meg kell tanulniuk a románt (ország nyelve), így sokan közülük azt tekintik ,idegen nyelvnek" és nem fektetnek hangsúlyt egy világnyelv elsajátítására, vagy ismernek idegen nyelveket, de valamilyen okból kifolyólag nem tartották fontosnak azt, hogy még az egyetemre való jelentkezés elött nyelvvizsgát szerezzenek.

11. Táblázat: A viszgált populáció nyelvizsga szerinti megoszlása

\begin{tabular}{|l|c|c|c|c|c|c|}
\hline $\begin{array}{c}\text { Van-e Ön- } \\
\text { nek nyelv- } \\
\text { vizsgája? }\end{array}$ & \multicolumn{7}{|c|}{ Nemzetiség } \\
\hline & magyar & $\%$ & román & $\%$ & \multicolumn{2}{|c|}{ összesen } \\
\hline igen & 26 & 16,45 & 59 & 37,34 & 85 & 53,79 \\
\hline nem & 61 & 38,125 & 12 & 7,59 & 73 & 46,20 \\
\hline összesen & 87 & 38,60 & 71 & 44,93 & 158 & 100 \\
\hline
\end{tabular}

Forrás: BBTE-DE EK TÁMOP kutatás adatfelvétele 


\section{TovábBTANUlás, A SZAK ÉS AZ EGYETEM VÁLASZTÁSA}

A továbbiakban az érdekelt minket, hogy honnan szereznek tudomást a hallgatók a Babeş-Bolyai Tudományegyetemröl, illetve a választott szakról.

Érdekesen alakultak a válaszok erre a kérdésre: döntő jellegünek bizonyult 24,2\%uk esetében az, hogy egy ismerősük ilyen szakra jár (ennél a pontnál választották a legtöbben a döntő jelleget). (12. táblázat)

12. Táblázat: Ismerőse jár ilyen szakra

\begin{tabular}{|l|c|c|}
\hline Ismerőse jár ilyen szakra & Fő & Százalék (\%) \\
\hline nem tudja, nem válaszolt & 5 & 3.1 \\
\hline egyáltalán nem & 43 & 26.7 \\
\hline csak kis mértékben & 29 & 18.0 \\
\hline nagy szerepet játszott & 29 & 18.0 \\
\hline döntõ mértékû & 39 & 24.2 \\
\hline hiányzó adat & 16 & 9.9 \\
\hline összesen & 161 & 100.0 \\
\hline
\end{tabular}

Forrás: BBTE-DE EK TÁMOP kutatás adatfelvétele

A szülőktől kapott információ a választott szakkal kapcsolatosan 41\%-nál egyáltalán nem befolyásolta a választást, 25,5\%-at csak kis mértékben befolyásolt. (13. táblázat)

13. Táblázat: A szülőktől kapott információ befolyása az adott szak választására

\begin{tabular}{|l|c|c|}
\hline Szülőktől kapott információt & Fő & Százalék (\%) \\
\hline nem tudja, nem válaszolt & 4 & 2.5 \\
\hline egyáltalán nem & 66 & 41.0 \\
\hline csak kis mértékben & 41 & 25.5 \\
\hline nagy szerepet játszott & 23 & 14.3 \\
\hline döntő mértékû & 14 & 8.7 \\
\hline hiányzó adat & 13 & 8.1 \\
\hline összesen & 161 & 100.0 \\
\hline
\end{tabular}

Forrás: BBTE-DE EK TÁMOP kutatás adatfelvétele 
Az iskolától, tanároktól szerzett információ még kevésbé befolyásolta a választást, 46\%-nál nem volt döntő jellegü. (14. táblázat) 14. Táblázat: Az iskolától, tanároktól kapott információ
befolyása az adott szak választására

\begin{tabular}{|l|c|c|}
\hline $\begin{array}{l}\text { Az iskolától, tanároktól } \\
\text { kapott információ }\end{array}$ & Fő & Százalék (\%) \\
\hline nem tudja, nem válaszolt & 3 & 1.9 \\
\hline egyáltalán nem & 74 & 46.0 \\
\hline csak kis mértékben & 42 & 26.1 \\
\hline nagy szerepet játszott & 16 & 9.9 \\
\hline döntõ mértékû & 13 & 8.1 \\
\hline hiányzó adat & 13 & 8.1 \\
\hline összesen & 161 & 100.0 \\
\hline
\end{tabular}

Forrás: BBTE-DE EK TÁMOP kutatás adatfelvétele

Az egyetemi nyílt napra 68,9\%-uk állította azt, hogy egyáltalán nem befolyásolta választását, döntő jellegüként csupán 0,6\%-uk jelölte meg, ami méretéből adódóan szinte elhanyagolható. (15. táblázat)

15. Táblázat: Az egyetemi nyílt napon kapott információt

\begin{tabular}{|l|c|c|}
\hline „Nyílt nap” & Fő & Százalék (\%) \\
\hline nem tudja, nem válaszolt & 8 & 5.0 \\
\hline egyáltalán nem & 111 & 68.9 \\
\hline csak kis mértékben & 13 & 8.1 \\
\hline nagy szerepet játszott & 12 & 7.5 \\
\hline döntő mértékü & 1 & .6 \\
\hline hiányzó adat & 16 & 9.9 \\
\hline összesen & 161 & 100.0 \\
\hline
\end{tabular}

Forrás: BBTE-DE EK TÁMOP kutatás adatfelvétele

A hallgatók többsége, 37,9\% azt állította, hogy azért választotta jelenlegi szakját, mivel „,́gy tudja megvalósítani elképzeléseit”. Ennél az állításnál a legmagasabb a döntő jellegü válasz. (16. táblázat) 
16. Táblázat: Így tudja megvalósítani elképzeléseit

\begin{tabular}{|l|c|c|}
\hline Így tudja megvalósítani elképzeléseit & Fő & Százalék (\%) \\
\hline nem tudja, nem válaszolt & 3 & 1.9 \\
\hline egyáltalán nem & 14 & 8.7 \\
\hline egy kicsit & 22 & 13.7 \\
\hline nagyrészt & 51 & 31.7 \\
\hline döntően & 61 & 37.9 \\
\hline hiányzó adat & 10 & 6.2 \\
\hline összesen & 161 & 100.0 \\
\hline
\end{tabular}

Forrás: BBTE-DE EK TÁMOP kutatás adatfelvétele

Szintén pozitív válasz figyelhető még meg az „ismerősei tanácsolták” lehetőségnél, ahol 24,2\%-uk azt állította, hogy ez igaz, egy „kicsit”, 24,8\%-uk, hogy „nagyrészt” és 14,3\%-uk pedig a „döntő módon” lehetöségeket választották.

A következő válaszlehetőségeknél azonban már csak a „nem” lehetőséget választották: „szüleim tanácsolták” (45,3\%), „tanáraim tanácsolták” (50,3\%), „ismerőseim, barátaim ide jelentkeztek” (47,8\%) és „,máshova nem vettek fel” $(70,8 \%)$.

Az eredmények azt mutatják, hogy a hallgatók jó része azért választotta a szakot, mert úgy érzi, ez az a szak, ami által megvalósíthatja elképzeléseit.

17. Táblázat: Ezzel a diplomával jól lehet keresni

\begin{tabular}{|l|c|c|}
\hline $\begin{array}{c}\text { Ezzel a diplomával jól } \\
\text { lehet keresni }\end{array}$ & Fö & Százalék (\%) \\
\hline nem tudja, nem válaszolt & 4 & 2.5 \\
\hline egyáltalán nem & 75 & 46.6 \\
\hline csak kis mértékben & 49 & 30.4 \\
\hline nagy szerepet játszott & 15 & 9.3 \\
\hline döntő mértékû & 6 & 3.7 \\
\hline hiányzó adat & 12 & 7.5 \\
\hline összesen & 161 & 100.0 \\
\hline
\end{tabular}

Forrás: BBTE-DE EK TÁMOP kutatás adatfelvétele 
A jelenlegi szak választásával kapcsolatosan a további kérdésekre kapott válaszok még inkább megerősítik, hogy a hallgatók saját elképzeléseik megvalósítása érdekében választották az adott szakot, és nem azért, mert esetleg jól lehetne keresni a szak nyújtot ta diplomával (46,6\%-uk azt állítja, hogy egyáltalán nem lehet jól keresni az adott szakterületen, lásd 18. Táblázat), s nem is azért, mert esetleg könnyen lehetett bejutni az adott szakra (nem: 53.4\%) vagy a felvételi tárgyak a kedvencei közé tartoztak (nem: 50,3\%), nem volt felvételi (nem: 62,1\%), alacsonyak voltak a követelmények (nem: $59 \%$ ) és a munkahely támogatása sem játszott szerepelt választásukban (nem: $75,8 \%$ ) (17. táblázat)

A vizsgálat következő kérdésével arra szerettünk volna választ kapni, hogy menynyire befolyásolták bizonyos tényezök abban, hogy egyetemre jelentkezzen.

A hallgatók többsége, $60,9 \%$ döntő jelentőséget tulajdonított a szakma iránti érdeklödésnek. (18. táblázat)

18. Táblázat: Ez a szakma érdekli

\begin{tabular}{|l|c|c|}
\hline Ez a szakma érdekli & Fő & Százalék (\%) \\
\hline nem tudja, nem válaszolt & 1 & 0.6 \\
\hline egyáltalán nem & 6 & 3.7 \\
\hline csak kis mértékben & 12 & 7.5 \\
\hline nagy szerepet játszott & 36 & 22.4 \\
\hline döntõ mértékû & 98 & 60.9 \\
\hline hiányzó adat & 8 & 5.0 \\
\hline összesen & 161 & 100.0 \\
\hline
\end{tabular}

Forrás: BBTE-DE EK TÁMOP kutatás adatfelvétele

36\%-uk szerint „döntő mértékünek” jelentőségünek illetve 36\% „nagyrészt a karrier felépítésének részeként" tekinti az adott egyetemre való jelentkezést. Amennyiben e két válaszlehetőséget összevonjuk, láthatjuk, hogy a hallgatók döntő többsége elengedhetetlennek látja az egyetemre való jelentkezést a karrierépités szempontjából. A hallgatók 36\%-a „döntően” válaszolt arra a kérdésre is, mely szerint „mindenképp diplomát" szeretne szerezni. (19. táblázat)

A hallgatók 31,7\% kevésbé tartja vonzónak a diákéletet, mint befolyásoló tényezőt az adott szak választása szempontjából.

A következő tényezőkre azonban a hallgatók többsége tagadó választ adott: „mindegy, hogy mit csinál, csak tanuljon” (egyáltalán nem, 62,7\%), „egyelöre nem szeretnének fóállásban dolgozni” (nem: 41\%), ,a jelenlegi munkájához szüksége van arra, hogy tanuljon” (egyáltalán nem: 62,7\%), „Szülei is diplomásak” (egyáltalán nem: 62,7\%), „munkahelyi elömenetelhez szükséges (nem: 45,3\%). 
A kapott eredmények arra engednek következtetni, hogy a hallgatókat nagyrészt a szakmával kapcsolatos érdeklődés, a karrier lehetősége motiválta a szakra való jelentkezéskor.

19. Táblázat: Az egyetem elvégzése a karrierépítés része

\begin{tabular}{|l|c|c|}
\hline Karriere felépítésének a része & Fő & Százalék (\%) \\
\hline nem tudja, nem válaszolt & 4 & 2.5 \\
\hline egyáltalán nem & 13 & 8.1 \\
\hline csak kis mértékben & 19 & 11.8 \\
\hline nagy szerepet játszott & 58 & 36.0 \\
\hline döntő mértékü & 58 & 36.0 \\
\hline hiányzó adat & 9 & 5.6 \\
\hline összesen & 161 & 100.0 \\
\hline
\end{tabular}

Forrás: BBTE-DE EK TÁMOP kutatás adatfelvétele

A vizsgálat következő kérdésére, a mennyire befolyásolták azt, hogy a Babeş-Bolyai Egyetemet választotta, kapott válaszok értelmében a hallgatók választása szerint döntő jelentőségü volt az, hogy a BBTE-nek jó híre van (36,6\%), a terület legjobb intézménye (36\%) illetve 25,5\%-nak fontossággal bírt az is, hogy tetszik neki a város. (20. táblázat)

20. Táblázat: mennyire befolyásolták azt, hogy a Babeş-Bolyai Egyetemet választotta

\begin{tabular}{|c|c|c|c|}
\hline \multicolumn{2}{|l|}{$\begin{array}{l}\text { Mennyire befolyásolták azt, hogy } \\
\text { a BBTE-t választotta }\end{array}$} & $\begin{array}{l}\text { Személyek } \\
\text { száma }\end{array}$ & $\begin{array}{l}\text { Százalék } \\
(\%)\end{array}$ \\
\hline BBTE jó híre & döntően & 59 & 36,6 \\
\hline BBTE a terület legjobb intézménye & döntően & 58 & 36 \\
\hline Tetszik a város & nagyrészt & 41 & $25,5 \%$ \\
\hline
\end{tabular}

Forrás: BBTE-DE EK TÁMOP kutatás adatfelvétele

Az eredmények azt mutatják, hogy a hallgatók tudatosan döntöttek a jó hírnevü, és a terület legjobb intézményeként elismert Babeş-Bolyai Tudományegyetem választása mellett. 


\section{A SZAK RANGSOROLÁSA ÉS AZ EGYETEMI KARRIER}

A saját szak rangsorolásakor az egyetem többi szakjához viszonyitva a hallgatók többsége a harmadik legelismertebb szakok közé sorolta azt, amire jár. Az okok, melyek miatt ide sorolták a szakot a következők: hasznosítható ismeretek $(39,1 \%)$, magas színvonal $(32,3 \%)$, érdekes tárgyak és ismeretanyag $(46,6 \%)$, színvonalas oktatás $(32,9 \%)$, színvonalas oktatók $(20,5 \%)$, a kialakult jó hírnév $(22,4 \%)$ valamint a jó tanár-diák viszony $(26,1 \%)$.

Az egyes szakokkal kapcsolatban gyakran megfogalmazott sztereotípiák felsorolásakor egyiknél sem észleltünk kiemelkedőt. A legmagasabb értéket az „Összetartó csapat, jó a csapatszellem” állításra kaptuk, mely esetében a „kérdezett” szerint az átlag 6,6 (kicsit átlagon felüli érték, ahol 1, az egyáltalán nem jellemző és 10 a teljes mértékben jellemző) míg „,mások szerint” 5,6 (ez nominális érték, kicsit átlagon felüli).

Arról, hogy az egyetem közvéleménye hova helyezi a hallgató által választott szakirányt, a vélemények azt mutatják (átlag 6.14), hogy a szak nem tartozik a legkevésbé elismertek közé, de nem is sorolható a legismertebb szakok közé. Ök maguk pedig az egyetem első kilenc szakja közé helyezik sajátjukat. Választási motivációjuk között szerepelnek a következők: értékes tananyag, ismeretanyag (46,6\%), hasznosító ismeretek $(39,1 \%)$, színvonalas oktatás $(32,9 \%)$, magas színvonal $(32,3 \%)$, jó tanár-diák viszony $(26,1 \%)$, a kialakult jó hírnév $(22,4 \%)$ valamint a színvonalas oktatók $(20,5 \%)$. (21. táblázat)

\section{Táblázat: Az egyetem „közvéleménye” hova helyezi az Ön szakját}

\begin{tabular}{|l|l|l|c|c|c|}
\hline $\begin{array}{l}\text { Mit, gondol arról, hogy az egyetem } \\
\text { „közvéleménye” hova helyezi az Ön } \\
\text { szakját }\end{array}$ & Fó & Minimum & Maximum & Átlag & Szórás \\
\hline & 155 & 1 & 10 & 6.14 & 2.03 \\
\hline Érvényes & 155 & & & & \\
\hline
\end{tabular}

Forrás: BBTE-DE EK TÁMOP kutatás adatfelvétele

A legfontosabb ok, ami miatt úgy gondolják, hogy erre a helyre sorolódik a szakjuk a következők: a „rossz elhelyezkedési esélyek” miatt $(22,4 \%)$ ezt követi majd a mert „nem ismerik, nem tudják milyen” (13,7\%).

Arra a kérdésre, hogy „,Mennyire fontosak a következö kijelentések az Ön számára?", a hallgatók többsége nagyon fontosként jelölte meg ,,a diplomát”, amit az adott szaknak elvégzése után kap (30,4\%), ezt követik a „felkészülni a választott szakmára” $(26,1 \%)$ valamint a „baráti kapcsolatok” $(22,4 \%)$. Fontosak továbbá a ,jó tanulmányi átlag” (27,3\%), TDK- munka (22,4\%), „elismerés a diáktársaitól” $(21,7 \%)$, „kapcsolatokat kialakítani, amelyek később -jól jönnek-” $(21,1 \%)$, „elismerés a tanároktól” $(19,3 \%)$, „kihasználni a müvelődés lehetőségeit” (19,3\%) valamint a „város le- 
hetőségei” $(18,6 \%)$. Három kijelentést tartottak „kicsit fontosnak”: „nyugodt élet, -ellenni- az egyetemen” (20,5\%), ,izgalmas élet, bulik” (16,8\%) valamint a „külföldi ösztöndíj” (15,5\%). (22. táblázat)

22. Táblázat: Mennyire fontosak a következő kijelentések az Ön számára?

\begin{tabular}{|c|c|c|}
\hline Mennyire fontosak a következő kijelentések az Ön szám & & Százalék (\%) \\
\hline A diploma & \multirow{3}{*}{$\begin{array}{l}\text { Nagyon } \\
\text { fontos }\end{array}$} & $30,4 \%$ \\
\hline Felkészülni a választott szakmára & & $26,1 \%$ \\
\hline Baráti kapcsolatok & & $22,4 \%$ \\
\hline jó tanulmányi átlag & \multirow{7}{*}{ Fontos } & $27,3 \%$ \\
\hline TDK- munka & & $22,4 \%$ \\
\hline elismerés a diáktársaitól & & $21,7 \%$ \\
\hline kapcsolatokat kialakítani, amelyek később „,jól jönnek” & & $21,1 \%$ \\
\hline elismerés a tanároktól & & $19,3 \%$ \\
\hline kihasználni a mủvelődés lehetőségeit & & $19,3 \%$ \\
\hline város lehetőségei & & $18,6 \%$ \\
\hline nyugodt élet "ellenni" az egyetemen & \multirow{3}{*}{$\begin{array}{l}\text { Kicsit } \\
\text { fontos }\end{array}$} & $20,5 \%$ \\
\hline izgalmas élet, bulik & & $16,8 \%$ \\
\hline külföldi ösztöndíj & & $15,5 \%$ \\
\hline
\end{tabular}

Forrás: BBTE-DE EK TÁMOP kutatás adatfelvétele

A fenti eredmények azt mutatják, hogy a hallgatók számára fontos az önmegvalósítás és a jó társas kapcsolatok kialakítása.

A jelenlegi helyzetükre és az egyetemi, föiskolai évek alatti céljaikra vonatkozóan azonban nem találtunk kiemelkedő választ. A résztvevők között körülbelül ugyananynyian vettek részt tanulmányi versenyen mint akik nem (21.7\%), kevesen vettek részt TDK tevékenységben (19.3\%), kevesen tartottak TDK konferencián elöadást (6.2\%), többen tervezik hogy a jövőben TDK konferencián tartanak majd előadást (11.8\%), kevés egyetemistának jelent meg publikációja (3.1\%), 7, 5\%-a a részt vett valamelyik tanára kutatásában, $15.5 \%$-a tervezi hogy jelentkezik PhD kurzusra, valamint 14.9\%-a tervezi csak hogy a jövőben tudományos munkát folytat. 17.4\%-a kapott kiemelt tanulmányi ösztöndíjat, 5\%-a kapott külföldi ösztöndíjat, 11.8\%-a tagja valamilyen diákszervezetnek és $2.5 \%$-a tagja valamilyen szakkollégiumnak. 3.7\%-a tagja valamilyen öntevékeny csoportnak. 


\section{A SUPER MUNKAÉRTÉK KÉRDÖÍV FÖBB EREDMÉNYEI}

Összehasonlítva a román és magyar hallgatók által kapott válaszokat, szignifkáns öszszefüggést találtunk a következő szinteken: változatosság, önérvényesítés, irányítás, altruizmus és anyagiak.

A magyar hallgatók esetében nagyobb jelentősége van a szak kiválasztásakor a változatosságnak (magyar: 12.22 átlag, ahol a minimum 3, a maximum érték 15, román: 10.69 átlag), az önérvényesítésnek (magyar: 12.72 átlag, román 11.19 átlag) és az altruizmusnak (magyar: 13.02 átlag, román: 12.27 átlag), mint a román hallgatók esetében.

Az irányítás (román: 11.66 átlag, magyar: 8.91 átlag) és az anyagiak (magyar: 10.73 átlag, román: 11.61 átlag) a román hallgatóknál fontosabbak, mint a magyar hallgatók esetében.

A többi változónál a két csoport átlaga nem különbözik egymástól, tehát ezekben az esetekben nincs különbség a román és magyar hallgatók között (lásd 1. Melléklet).

A továbbiakban a változók csoportosítása és számuk redukálása céljából faktoranalízist végeztünk. A változók közötti összefüggések feltárásával, lehetővé vált a közvetlenül nem megfigyelhető háttérváltozók, faktorok, meghatározása is. Három, eltérő faktorelemzést készítettünk, hiszen fontosnak tartottuk, hogy a magyar-, és román minta faktorai mellett a teljes minta faktorait is feltárjuk. Csak így valósítható meg a magyar- és román minták összehasonlítása.

Az adatok statisztikai feldolgozása során összefüggést találtunk bizonyos faktorok között (lásd 2 Melléklet). Ennek alapján arra következtethettünk, hogy azok a hallga tók, akiknél az altruizmus dominál, fontosnak tartják még a változatosságot, az esztétikumot, a társas kapcsolatokat, az önérvényesítést, a munkateljesítményt és a kreativitást. Érdekes módon azoknál a hallgatóknál, akiknél az anyagiak dominálnak, szintén megjelenik a változatosság, mint fontos faktor, de emellett a függetlenség, a presztízs, az esztétikum, az önérvényesítés, a hierarchia, az irányítás és kreativitás. Azok a hallgatók, akiknél a változatosság dominál, a függetlenséget, a társas kapcsolatokat, az önérvényesítést, a fizikai környezetet, a munkateljesítményt valamint a kreativitást tartják fontosnak.

Fontos megjegyeznünk, hogy teszten belüli kérdésekről van szó, és nem túl erős korrelációk ezek.

A továbbiakban faktoranalízist készítettünk mind a magyar mind a román mintákra illetve a teljes mintára. A ,principal component” módszert alkalmaztuk.

A Bartlett-teszt azt vizsgálja, hogy a változók az alapsokaságban korrelálatlanok-e (nullhipotézis), azaz azt teszteli, hogy a korrelációs mátrixnak a fóátlón kívüli elemei csak véletlenül térnek-e el a nullától. ${ }^{1}$ Kaiser-Meyer-Olkin- (KMO) kritérium az egyik legfontosabb mérőszám annak megítélésében, hogy a változók mennyire alkalmasak a faktorelemzésre. ${ }^{2}$

1. Sajtos-Mitev, 2006, p.257.

2. ibidem 


\section{A magyar minta faktorsúly mátrixai:}

\begin{tabular}{|l|c|}
\begin{tabular}{|l|c|}
\hline Értékkör & Faktorsúly \\
\hline Anyagiak & .872 \\
\hline Presztízs & .663 \\
\hline Önérvényesítés & .571 \\
\hline Irányítás & .720 \\
\hline Kreativitás & .436 \\
\hline
\end{tabular}
\end{tabular}

A preferált értékkörök többségével jellemezhető ez a faktor. Ide tartoznak az anyagiak, a presztízs, az önérvényesítés, irányítás valamint a kreativitás. Ezek azok az értékkörök, melyeket mindenképp el szeretnének érni a hallgatók. Az értékkörök közös lényege talán leginkább a hatalom fogalmában foglalható össze.

2. Faktor

\begin{tabular}{|l|c|}
\hline Értékkör & Faktorsúly \\
\hline Szellemi ösztönzés & .872 \\
\hline Függetlenség & .663 \\
\hline Munkával kapcsolatos biztonság & .571 \\
\hline Fizikai környezet & .720 \\
\hline
\end{tabular}

Ez a faktor az elvárt munkával kapcsolatos értékeket tartalmazza. Preferált értékkörök a: szellemi ösztönzés, a függetlenség, a munkával kapcsolatos biztonság valamint a fizikai környezet. A diákok számára motiváló tényezőként ható értékek ezek. Talán a szabadság fogalmában foglalható össze.

\begin{tabular}{|l|c|}
\multicolumn{2}{|c}{ 3. Faktor } \\
\begin{tabular}{|l|c|}
\hline Értékkör & Faktorsúly \\
\hline Altruizmus & .551 \\
\hline Hierarchia & .773 \\
\hline Munkateljesítmény & .715 \\
\hline
\end{tabular}
\end{tabular}

Leginkább az önérvényesités fogalmában foglalható össze ez a faktor, hiszen megtalálható benne a hierarchia, a munkateljesítmény valamint az altruizmus, mint preferált ér- 
tékkörök. Fontosnak tartjuk kiemelni az altruizmus jelenlétét, mely rohanó világunkban egyre kevésbé hangsúlyozódik ki mint munkaértéki preferencia, pedig a segítő szakmának ez elengedhetetlen feltétele. Érdekesnek tartanánk, ha a jövőre nézve nagyobb mintára is kiterjesztenénk a vizsgálatot, hogy ne csak a magyar-román minta közötti hasonlóságokat és eltéréseket tárjuk fel, hanem a különböző szakok hallgatóinak munkaérték preferenciáját is össze tudjuk hasonlítani. Megjegyezzük, hogy Magyarországon már készültek hasonló jellegü kutatások (Fónai, 2009), érdemes lenne majd ezekhez az eredményekhez hasonlítani a későbbi kutatási eredményeket.

\begin{tabular}{|c|c|}
\hline \multicolumn{2}{|c|}{ 4. Faktor } \\
\hline Értékkör & Faktorsúly \\
\hline Változatosság & .536 \\
\hline Esztétikum & .759 \\
\hline Társas kapcsolatok & .553 \\
\hline
\end{tabular}

Ez a faktor preferált és elutasított értékeket egyaránt tartalmaz. A magyar minta esetében a változatosság, mint elutasított értékkör jelenik meg, míg az esztétikum és a társas kapcsolatok preferált értékkörök. Talán a szociabilitás faktor lehetne.

\section{A román minta faktorsúly mátrixai:}

1. Faktor
\begin{tabular}{|l|c|}
\hline Értékkör & Faktorsúly \\
\hline Altruizmus & .772 \\
\hline Változatosság & .696 \\
\hline Presztízs & .642 \\
\hline Esztétikum & .528 \\
\hline Társas kapcsolatok & .835 \\
\hline Önérvényesítés & .492 \\
\hline Munkateljesítmény & .471 \\
\hline
\end{tabular}

A preferált értékkörök többségével jellemezhető ez a faktor. A presztízs és az önérvényesítés a magyar minta 1 faktorában is megjelent, mint preferált értékkör. Ez a két értékkör közös mindkét minta 1 faktoránál. Talán az önmegvalósítás fogalma áll a legközelebb tartalmához. 
2. Faktor

\begin{tabular}{|l|c|}
\hline Értékkör & Faktorsúly \\
\hline Szellemi ösztönzés & .803 \\
\hline Függetlenség & .791 \\
\hline Fizikai környezet & .539 \\
\hline Irányítás & .585 \\
\hline Kreativitás & .609 \\
\hline
\end{tabular}

A román minta második faktorában megjelenő öt értékkör közül három (szellemi ösztönzés, függetlenség és fizikai környezet) közös a magyar minta második faktorában megjelent értékkörökkel. Ez esetben a már említett három értékkör kiegészül a kreativitás és az irányítás értékkörökkel. A faktor tartalmához talán az önkifejezés fogalma áll legközelebb.

3. Faktor
\begin{tabular}{|l|c|}
\hline Értékkör & Faktorsúly \\
\hline Anyagiak & .846 \\
\hline Hierarchia & .772 \\
\hline
\end{tabular}

Lényegét tekintve ez a faktor nagyon hasonlít a magyar minta első faktorához.

4. Faktor

\begin{tabular}{|l|c|}
\hline Értékkör & Faktorsúly \\
\hline Munkával kapcsolatos biztonság & .948 \\
\hline
\end{tabular}

Ez a faktor a legpreferáltabb értékkört tartalmazza nagy faktorsúllyal és lényege önmaga. Úgy gondoljuk, hogy nem véletlen jelenik meg ez az értékkör, mint preferált értékkör, hiszen az elmúlt évek társadalmi váltságainak hatására a hallgatók fontosnak tartják, hogy legalább a munka területen megtalálják a biztonságot.

Ahhoz, hogy a faktorok összehasonlíthatóak legyenek, a két mintát közösen kell elemezni, közös faktorokat kell keresni. A további elemzés a közös faktorokkal történik. 


\begin{tabular}{|c|c|}
\hline \multicolumn{2}{|c|}{ 1. Faktor } \\
\hline Értékkör & Faktorsúly \\
\hline Presztízs & .225 \\
\hline Társas kapcsolatok & .317 \\
\hline Hierarchia & .551 \\
\hline Munkateljesítmény & .190 \\
\hline
\end{tabular}

Az első közös faktorhoz tartozó preferált értékkörök a presztízs, a társas kapcsolatok, a hierarchia valamint a munkateljesítmény. Hangsúlyoznunk kell, a társas kapcsolatok jelenlétét a preferált értékkörök között, hiszen ez az eredmény ellentmond Super tapasztalatának, mely szerint a felsőfokú végzettségủek nem tartják fontosnak a humán értékeket, azonban hasonló ahhoz, amiről Fónai és kutatócsoportja számolt be (Fónai, et al, 2010). A faktor tartalmához talán a humánus hatalom fogalma áll a legközelebb.

2. Faktor

\begin{tabular}{|l|c|}
\hline Értékkör & Faktorsúly \\
\hline Változatosság & .593 \\
\hline Függetlenség & .230 \\
\hline Esztétikum & .390 \\
\hline Kreativitás & .180 \\
\hline
\end{tabular}

A faktor preferált és elutasított értékeket egyaránt tartalmaz. Az esztétikum, mint elutasított értékkör jelenik meg, míg a változatosság, a függetlenség és a kreativitás preferált értékkörök. Úgy gondoljuk, hogy az esztétikum elutasítása nem véletlen, hiszen a vizsgálatban résztvevő hallgatok többsége nem müvészeti szakirány hallgatója. A preferált értékkörökhöz a szabadság jelző áll a legközelebb.

\begin{tabular}{|c|c|}
\hline \multicolumn{2}{|c|}{ 3. Faktor } \\
\hline Értékkör & Faktorsúly \\
\hline Szellemi ösztönzés & .156 \\
\hline Fizikai környezet & .160 \\
\hline Irányítás & .722 \\
\hline
\end{tabular}

Az irányítás meglehetősen magas faktorsúlyt kapott. Nem elhanyagolható az a tény, hogy a fizikai környezet is jelen van a preferált értékek között, ez arra enged minket 
következtetni, hogy a hallgatók számára a munkakörnyezet fontos tényezö, amit szem elött tartanak mielött elköteleznék magukat egy adott munka mellett. Lényegét tekintve e faktorhoz az önkifejezés fogalma áll a legközelebb.

4. Faktor

\begin{tabular}{|l|c|}
\hline Értékkör & Faktorsúly \\
\hline Munkával kapcsolatos biztonság & .634 \\
\hline Önérvényesítés & .195 \\
\hline
\end{tabular}

Ebbe a faktorba a ranghelyeket tekintve a középső harmadba sorolt értékkörök tartoznak. Talán a biztonság faktor lehetne.

5. Faktor
\begin{tabular}{|l|c|}
\hline Értékkör & Faktorsúly \\
\hline Altruizmus & .427 \\
\hline Anyagiak & .740 \\
\hline
\end{tabular}

Ez a faktor egy elutasított (altruizmus) és egy nagymértékben preferált nagy faktorsúlyú értékkört (anyagiak) tartalmaz és lényege ez utóbbi.

A biztonság és az anyagiak, mint értékek választása alátámasztja azt a feltételezésünket, mely szerint az elmúlt évek társadalmi folyamatainak, váltságainak hatására a hallgatók biztonságra vágynak, mely elképzelhetetlen a megfelelő anyagi háttér nélkül.

A következőkben azt vizsgáltuk, hogy van-e különbség a két minta között a fenti öt faktor tekintetében (Lásd 3. Melléklet). A következö faktoroknál találtunk különbségeket: a szabadság és biztonság (2. Faktor és a 4. Faktor) fontosabb a pályaválasztás szempontjából a magyar hallgatók számára, mint a román hallgatók számára, míg az önkifejezés (3. Faktor) a román hallgatók számára bír nagyobb fontossággal. (23. táblázat)

23. Táblázat: Az egyes faktorok átlagértéke

\begin{tabular}{|l|l|l|l|l|l|}
\hline minta & 1 Faktor & 2 Faktor & 3. Faktor & 4. Faktor & 5. Faktor \\
\hline magyar & -0.01272 & 0.322362 & -0.40698 & 0.205878 & -0.1351 \\
\hline román & 0.016751 & -0.42444 & 0.535856 & -0.27107 & 0.177883 \\
\hline
\end{tabular}

A kapott eredmények azt mutatják, hogy mindkét alminta esetén négy faktort lehetett elkülöníteni. Teljességében csupán a negyedik faktor különbözik, a többi esetében közös értékpreferenciák vannak.

A teljes minta esetén öt faktort különítettünk el. Az első faktor tartalmazza a presztízst, társas kapcsolatokat, hierarchiát és munkateljesítményt; a második faktort alkot- 
ják a változatosság, függetlenség, esztétikum és kreativitás; a harmadik faktorhoz tartoznak a szellemi ösztönzés, fizikai környezet és irányítás; a negyedik faktor tartalmazza a munkával kapcsolatos biztonságot és önérvényesítést, míg az ötödik faktorba az altruizmus és az anyagiak tartoznak (érdekes ez utóbbi párosítás).

Ha ezt az eredményt összehasonlítjuk előző kutatások eredményeivel (Kiss, 2001), eltéréseket észlelhetünk.

Szilágyi (1983) hat faktort azonosított (intellektuális érték, irányítás, altruizmus, társas kapcsolatok, anyagiak, függetlenség), a Benson-féle vizsgálatban (Benson, 1985) három faktort különítettek el (intellektuális érték, anyagiak - presztízs- irányítás, társas kapcsolatok) míg Kiss (1998) vizsgálataiban öt faktor lett elkülönítve. Ez utóbbi faktorszám megegyezik a teljes mintánk azonosított faktorszámával. A Kiss-féle vizsgálat (Kiss, 1998) első faktorába tartoznak a: presztízs, anyagiak, függetlenség és irányítás; a másodikba az intellektuális értékek, esztétikum, változatosság és önérvényesítés; a harmadikba az: önérvényesítés, játékosság és változatosság; a negyedikbe egy fóérték, a munkateljesítménye tartozott, míg az ötödikbe, hasonlóan a negyedik faktorhoz, ugyancsak egy föérték tartozott: a humán értékek. Egy későbbi vizsgálatában, Kiss négy nemzeti szociális munkás szakos hallgatóinak munkaérték preferenciáját vizsgálta, és azt találta, hogy a faktorok száma 4-5 faktor mentén állandósulni látszik, és a faktorok struktúrája a mintán belül több hasonlóságot mutat, mint más szakmák esetében.

\section{ÖsszeGZÉs}

Jelen dolgozatunk kettős célt követett: egyrészt azt, hogy bemutassa a szociológiai és szociális munka, bölcsészettudományi, mủvészeti, neveléstudományi, pszichológiai, társadalomtudományi, jogi politikai, közigazgatási, európai és teológiai, egyházi, vallási karok hallgatóinak sajátos, munkával kapcsolatos értékorientációját másrészt pedig feltárja a magyar és román anyanyelvű hallgatók értéksorrendjében jelentkező sajátosságokat.

A vizsgálatban összesen 161 nappali tagozatra járó egyetemi hallgató vett részt, 54,7\%-uk magyar és 45,3\% román nemzetiségü volt. Többségük nő volt.

A teljes minta (román és magyar) hallgatói túlnyomórészt városi, állami finanszírozású gimnáziumokból jöttek az egyetemre. Többségük nyelvvizsgával rendelkezik. Összehasonlítva a magyar és román mintát, láthatjuk, hogy a nyelvvizsgával rendelkező hallgatók 2/3-a román mintából került ki. Érdekességképpen megemlítjük, hogy a hallgatók túlnyomó részének ismerőse jár a választott szakra, és általa szerzett tudomást a szakról. Nem észleltünk kiemelkedő sztereotípiát az egyes szakokkal kapcsolatban gyakran megfogalmazott sztereotípiák felsorolásakor. Többségük állítja, hogy azért választotta az adott szakirányt, mert "így tudja megvalósítani elképzeléseit". Ugyanakkor a saját szak rangsorolásakor, a harmadik legelismertebb szakok közé sorolta azt, amire jár.

A munkával kapcsolatos értékpreferenciákat illetően a magyar minta hallgatóinál nagyobb jelentősége van a változatosságnak, az önérvényesítésnek és az altruizmusnak, míg a román minta hallgatói számára az irányítás és az anyagiak fontosabbak.

A teljes minta közös faktorai a hatalom, a szabadság, az önkifejezés valamint a biz- 
tonság. Biztatónak véljük a jövő szakembereire nézve, hogy a felsorolt faktorok mellett megtalálható a szabadság faktora is, hiszen ez a változatosság és függetlenség mellett tartalmazza a kreativitást is.

Vizsgálatunk által sikerült rávilágítanunk a magyar és román anyanyelvű hallgatók értéksorrendjének sajátosságaira Továbbá, fontosnak tartjuk hangsúlyozni egy későbbi kutatás szükségességét, mely nagyobb mintára terjedne ki annak érdekében, hogy a különböző szakos egyetemi hallgatók munkaérték preferenciája közötti különbségeket is feltárja.

\section{Felhasznált irodalom}

1. Asztalos Lajos, Kolozsvár rövid története, http: //www.magyarnapok.ro/index.php

2. Az egyetem számokban, http://www.ubbcluj.ro/hu/despre/

3. Benson Katalin (1985): Orvosegyetemi hallgatók körében végzett vizsgálatok öszszehasonlító elemzése FPK Tanulmánykötet, Budapest

4. Comisia Judeţeană pentru Recensământul Populaţiei şi al locuinţelor, Judeţul Cluj Comunicat De Presă privind rezultatele provizorii ale Recensământului Populaţiei şi Locuinţelor - 201, 12 februarie 2012

5. Fónai - Zolnai E - Kiss J: A hallgatók munkaérték preferenciái. In: Pusztai Gabriella (szerk.): Régió és oktatás európai dimenzióban. Debrecen: Doktoranduszok Kiss Árpád Közhasznú Egyesülete, 2005. pp. 190-205. (ISBN 9632175859 ), jog.unideb.hu/documents/detep/FM.doc

6. Fónai, Mihály - Kiss, János - Márton, Sándor - Zolnai, Erika (2010): Characteristics of the Work Value Choices of the University Students. In: Fedor, A - Semsei, I (eds): Twenty Years of Health Care Education and Social Sciences at the Faculty of Health Medical and Health Science Center University of Debrecen. Nyíregyháza: Faculty of Health Medical and Health Science Center, pp. 38-60. http://www.doktori.hu/index.php?menuid=192\&sz_ID $=2194$

7. Kiss János (1998): Munkaérték preferenciák vizsgálata szociális munkás hallgatóknál. In.: DOTE E.F.K. Tudományos Közleményei, szerk. Fónai Mihály, Nyíregyháza

8. Kiss János (2001): Szociális munkás szakos hallgatók munkaérték preferenciáinak nemzetközi összehasonlítása, -tanulmány, mely az OTKA T 017955 sz. Pályázat keretében készült

9. Kolozsvár története, http://www.kolozsvar.com/kvar/tortenete.html

10. SAJTOS, L., MITEV, A. (2007): SPSS kutatási és adatelemzési kézikönyv. Alinea Kiadó, Budapest

11. Sípos Gábor, Az egyetem története, http://www.ubbcluj.ro

12. Szilágyi Klára (1938): Tanulmányaikat befejező egyetemi és föiskolai hallgatók értékválasztásának eredményei. Pályaválasztás 1983/4. 
